\title{
EXPERIMENTAL PHARMACOLOGICAL RESEARCH REGARDING THE EFFECT OF SOME NEWLY SYNTHESIZED B-PHENYLETHYL AMINES ON THE MODIFIED PARAMETERS OF THE LIPID METABOLISM
}

\author{
EMIL ȘTEFĂNESCU ${ }^{1 \#}$, ELENA MOROȘAN ${ }^{2 \#}$, HOREA GURGU ${ }^{3 *}$, ISABEL CRISTINA \\ VIORICA GHIȚA ${ }^{4 \#}$, ANCA ZANFIRESCU ${ }^{1 *}$, CRISTINA ELENA ZBÂRCEA ${ }^{1}$, OVIDIU MUȘAT ${ }^{5}$, \\ SIMONA NEGREȘ ${ }^{1}$
}

\author{
${ }^{I}$ Pharmacology and Clinical Pharmacy Department, Faculty of Pharmacy, "Carol Davila" University of Medicine and \\ Pharmacy, 6 Traian Vuia Street, 020956, Bucharest, Romania \\ ${ }^{2}$ Clinical Laboratory and Food Hygiene Department, Faculty of Pharmacy, "Carol Davila" University of Medicine and \\ Pharmacy, 6 Traian Vuia Street, 020956, Bucharest, Romania \\ ${ }^{3}$ Pharmaceutical Chemistry Department, Faculty of Pharmacy, "Carol Davila” University of Medicine and Pharmacy, 6 \\ Traian Vuia Street, 020956, Bucharest, Romania \\ ${ }^{4}$ Pharmacology Department, Faculty of Medicine, "Carol Davila" University of Medicine and Pharmacy, 8 Eroii Sanitari \\ Street, 050474, Bucharest, Romania \\ ${ }^{5}$ Central Military Emergency Hospital,139 Calea Plevnei Street, 010825, Bucharest, Romania
}

*corresponding author: zanfirescuanca@yahoo.com

\#Authors with equal contribution

Manuscript received: October 2018

\begin{abstract}
The effect of some new $\beta$-phenylethylamine derivatives on some parameters of the lipid metabolism and lipid peroxidation was investigated. The research method used was based on inducing hyperlipidaemia in rats by administering orally $4 \%$ triton in a dose of $400 \mathrm{mg} / \mathrm{kg}$ bw. The new compounds were tested against fenofibrate, the reference substance. The results have shown that compounds coded $\mathrm{C} 2$ and $\mathrm{A} 1$ induced a decrease in the total cholesterol levels, that was higher than that generated by the reference substance, compared to the control group with hyperlipidaemia. Furthermore, compounds coded C2, A6 and C3 have lowered LDL-cholesterol levels more efficiently than fenofibrate, in the hyperlipidaemia control group. All compounds except for $\mathrm{C} 1$ increased HDL-cholesterol levels more than the reference substance in the hyperlipidaemia control group. All compounds lowered the malonyl dialdehyde liver concentration, as a biomarker of lipid peroxidation, compared to the hyperlipemic control group. According to our results, the newly synthesized $\beta$-phenylethylamine derivatives have a statistically significant positive impact on the parameters of the lipid metabolism, possibly due to a $\beta_{3^{-}}$adrenergic receptors agonist mechanism.
\end{abstract}

\section{Rezumat}

A fost evaluat efectul unor compuşi nou sintetizați cu nucleu beta-feniletilaminic asupra parametrilor metabolismului lipidic și asupra peroxidării lipidice. Metoda de cercetare folosită s-a bazat pe inducerea hiperlipemiei la şobolan prin administrarea orală a $400 \mathrm{mg} / \mathrm{kg}$ corp triton $4 \%$. Compuși au fost administrați pe cale orală, comparativ cu fenofibratul, utilizat ca substanță de referință. Rezultatele au arătat că doi dintre compuși, notați C2 și A1 au determinat scăderi ale colesterolului total mai mari decât cele induse de fenofibrat la șobolanii hiperlipemici. Compușii C2, A6 și C3 au determinat scăderi ale LDL colesterolului mai mari decât cele induse de fenofibrat față de martorul hiperlipemic. Toate substanțele au determinat creșteri ale HDL colesterolului, respectiv scăderi ale trigliceridelor serice (cu excepția C1), mai mari decât cele induse de fenofibrat la șobolanii hiperlipemici. Toate substanțele au scăzut concentrația malonildialdehidei hepatice, ca marker al peroxidării lipidice, comparativ cu lotul martor hiperlipemic. Conform rezultatelor obținute, substanțele nou-sintetizate prezintă efecte benefice semnificative statistic asupra parametrilor metabolismului lipidic, posibil printr-un mecanism de tip agonist asupra receptorilor beta-3 adrenergici.

Keywords: $\beta$-phenylethylamine, triton, hyperlipidaemia, $\beta_{3}$ agonist

\section{Introduction}

Lipid metabolism dysfunctions that occur in obesity are increasing in Europe and North America, therefore the research in the direction of finding new remedies for these conditions are of maxim interest [6].
The involvement of the adrenergic transmission via $\beta_{3}$ receptors in modulating the lipid metabolism was demonstrated in preclinical researches [20]. Studies on obese rodents treated with $\beta_{3}$ adrenergic receptors 
agonists $[18,19]$ have shown a significant decrease in their body mass and a reduction of adipose tissue without affecting the daily diet ratios. Comparative studies on normal and genetically modified mice without $\beta_{3}$ adrenergic receptors have revealed an inversely proportional correlation between the fat levels and the number of $\beta_{3}$ adrenergic receptors [15]. Furthermore, in models of genetically induced obesity in mice and rats, a decrease in RNAm levels within $\beta_{3}$ adrenergic receptors was observed [7, 8].

New potential $\beta_{3}$ adrenergic receptors agonists are being developed and investigated all over the world
$[2,23]$. Although at present several in vitro methods are available for preclinical trials [17] animal testing remains an essential step for introducing new drugs in therapy.

We previously reported the synthesis and development of some new compounds that have a common $\beta$ phenylethylamine structure and different substituted radicals, which give each substance a different affinity for $\beta_{3}$ adrenergic receptors and a different diffusion level in various body compartments $[1,3,12]$. We coded the series of the new molecules as the A series (Figure 1) and the $\mathrm{C}$ series (Figure 2) $[4,5]$.

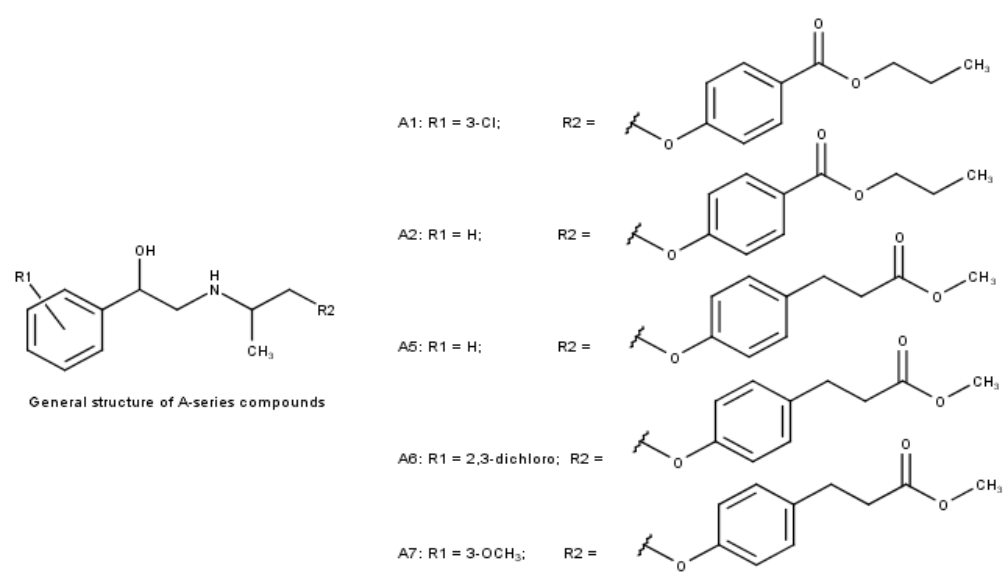

Figure 1.

Chemical structure of the tested compounds belonging to A-series

(A1: propyl-4-(2-((2-(3-chlorophenyl)-2-hydroxyethyl)amino)propoxy)benzoate, A2: propyl-4-(2-((2-hydroxy-2-phenylethyl)amino)propoxy)benzoate, A5: methyl-3-(4-(2-((2-hydroxy-2-phenylethyl)amino)propoxy)phenyl)propanoate, A6: methyl-3-(4-(2-((2-(2,3-dichlorophenyl)-2-hydroxyethyl)amino)propoxy)phenyl)propanoate, A7: methyl-3-(4-(2-((2hydroxy-2-(3-metoxyphenyl)ethyl)amino)propoxy)phenyl)propanoate)<smiles>[2H]CC(C)NCC(O)c1ccccc1</smiles>

General structure of C-series compounds

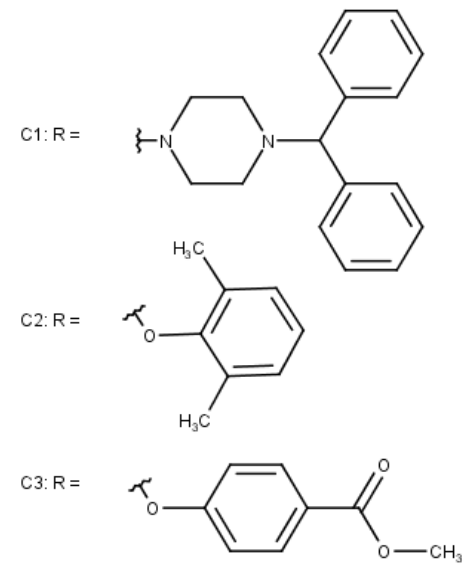

Figure 2.

Chemical structure of the tested compounds belonging to $\mathrm{C}$-series

(C1: 2-((1-(4-benzhydrylpiperazin-1-yl) propan-2-yl)amino)-1-phenylethanol, C2: 2-((1-(2,6-dimethylphenoxy)propan-2yl)amino)-1-phenylethanol, C3: methyl-4-(2-((2-hydroxy-2-phenylethyl)amino)propoxy)benzoate)

Based on suggestive literature data regarding the benefits of $\beta_{3}$ adrenergic agonists an modulating the lipid metabolism, we further investigated the potential pharmacological effects of our new molecules in this field. 


\section{Materials and Methods}

\section{Reagents}

Fenofibrate (Terapia SA, Romania), triton WR-1339, thiobarbituric acid, trichloracetic, 4-aminoantipyrine, phenol, tris-buffer-saline were used. All chemicals were of analytical grade and used without further purification. The tested new molecules employed were A1, A2, A5, A6, A7 from the A-series and C1, $\mathrm{C} 2, \mathrm{C} 3$ from the $\mathrm{C}$-series and were provided by the National Institute for Chemical - Pharmaceutical Research and Development (ICCF) Bucharest, Romania. Commercially available kits were used for the biochemical assays: total cholesterol (TC; Liquick CorChol 60 No. 2-204; Cormay, Lublin, Poland), HDLcholesterol (HDL-C; Olympus Diagnostica GmbH No. OSR 6287; Hamburg, Germany) and triacylglycerides (TG; Liquick Cor-TG 30 No. 2-262; Cormay, Lublin, Poland), as described by Kostogrys et al. The LDL and VLDL-cholesterol were calculated as the difference between TC and HDL-cholesterol [9, 10].

Animals

110 Wistar male white rats weighing $249.5 \pm 48.5 \mathrm{~g}$ $(\mathrm{M} \pm \mathrm{SD})$ was purchased from the "Carol Davila" University of Medicine and Pharmacy, Bucharest, Romania animal facility complex. After an accommodation period of 5 days, the animals were divided in 11 groups (10 rodents/group) and housed in individual cages, separately ventilated, having ad libitum access to water and dry food granules. The temperature of the housing environment was $20-22^{\circ} \mathrm{C}$ and the relative humidity was maintained at $35-45 \%$.

All experiments were conducted in accordance with EU Directive 63/2010 on the protection of animals used for scientific purposes. The protocol was approved by the "Carol Davila" University of Medicine and Pharmacy, Bucharest, Romania, Bioethics Committee. The doses were chosen in accordance with the $\mathrm{LD}_{50}$ previously determined for each substance [12]. The new compounds were administered orally, as aqueous suspensions, in 4 consecutive days, as follows: $20 \mathrm{mg} /$ $\mathrm{kg}$ bw C1 $0.2 \% ; 50 \mathrm{mg} / \mathrm{kg}$ bw C2 $0.5 \% ; 100 \mathrm{mg} / \mathrm{kg}$ bw C3, A1, A2, A5, A6 and A7 1\%. The control group received distilled water $1 \mathrm{~mL} / 100 \mathrm{~g}$ bw, while the reference group was treated with $100 \mathrm{mg} / \mathrm{kg}$ bw fenofibrate $1 \%$. In the $2^{\text {nd }}$ day, the hyperlipidaemia inducing agent was administered $(400 \mathrm{mg} / \mathrm{kg}$ bw triton $4 \%$ ) [9]. In the $4^{\text {th }}$ day of the experiment, the animals were euthanized. Blood was collected from the neck into glass tubes and the serum was obtained from blood samples after centrifugation $(1000 \mathrm{rpm}, 10 \mathrm{~min}$ at $4^{\circ} \mathrm{C}$ ). Liver samples were also harvested on ice. LDL-, HDL-, total cholesterol and triglyceride serum levels were assessed, as well as the hepatic malondialdehyde (MDA) concentration. Hepatic samples were fragmented and approximately $1 \mathrm{~g}$ of tissue was weighted and added in a glass homogenizer with $10 \mathrm{~mL}$ $0.1 \mathrm{M}$ tris- $\mathrm{KCl}$ for homogenate preparation and the resulting liver homogenate was centrifuged for 10 minutes at $3000 \mathrm{rpm}$. MDA levels were determined (Halo DB-20 Dynamica, Great Britain), based on previously described methods $[13,16]$. Results were expressed as nmols MDA/mg proteins in the studied samples [14]. The pharmacological effect was also quantified in terms of $\%$ effect versus the control group. Statistical analysis

The statistical evaluation of the results was performed using the software - GraphPad Prism version 5.01. This software analyses populations with normal distribution using the Student's t test (for 2 groups) and the ANOVA test (for multiple groups). In case of statistical significance in the ANOVA test ( $p<0.05)$, a further post-test was employed (Dunnett). The normality of the distribution was determined using the D`AgostinoPearson (D\&P) test.

\section{Results and Discussion}

The administration of our new $\beta$-phenylethylamine molecules, to the studied groups of animals, revealed important variations of the investigated lipidic parameters, as shown in Tables I - IV.

After administering a dose of $400 \mathrm{mg} / \mathrm{kg}$ bw triton $4 \%$, a significant disruption of the normal equilibrium in the lipid metabolism parameters was induced: total cholesterol levels increased by $176.88 \%$, LDLcholesterol levels increased by $347.76 \%$, HDLcholesterol decreased by $19.57 \%$ and triglyceride levels increased by $155.31 \%$.

Fenofibrate induced a high statistically significant decrease in total cholesterol levels compared to the hyperlipidaemia control group (by 59.99\%). All tested compounds induced a significant decrease of this parameter compared to the hyperlipidaemia control group (Table I, Figure 3), but compounds C2 and A1 had the most intense effect, decreasing total cholesterol levels by more than $60 \%$. Similar data were obtained for compounds $\mathrm{C} 1, \mathrm{C} 3, \mathrm{~A} 2, \mathrm{~A} 6$ and A7, that lowered this parameter by more than $45 \%$, while A5 compound showed the lowest anticholesterol effect.

All tested compounds induced a statistically significant decrease in LDL cholesterol levels compared to the hyperlipidaemia control group (Table II, Figure 4). Most of our compounds decreased this biomarker by more than $70 \%$, only $\mathrm{C} 1$ molecule showed less than $60 \%$ effect.

Regarding HDL-cholesterol values, a significant effect was observed in compounds $\mathrm{C} 3$ and A5 that increased this biomarker by more than $130 \%$ and, respectively, almost 115\% (Table III, Figure 5).

Total serum triglycerides were lowered by more than $60 \%$ (Table IV, Figure 6), compared to the hyperlipidaemia control group. In this case, the most effective derivatives proved to be $\mathrm{A} 6$ and $\mathrm{A} 7$ which developed the most significant effect $(>70 \%)$. 
Variation of mean total cholesterol levels (mg/dL) compared to the control groups

\begin{tabular}{|c|c|c|c|c|c|c|c|c|c|c|c|}
\hline Parameter & $\begin{array}{c}\text { Normal } \\
\text { Control } \\
(\mathrm{NC}) \\
\end{array}$ & $\begin{array}{c}\text { Hyperlip } \\
\text { Control } \\
(\mathrm{HC})\end{array}$ & Ref & $\mathrm{C} 1$ & $\mathrm{C} 2$ & $\mathrm{C} 3$ & A1 & A2 & A5 & A6 & A7 \\
\hline $\mathrm{M} \pm \mathrm{SEM}$ & $\begin{array}{c}54.4 \pm \\
5.35\end{array}$ & $\begin{array}{c}150.9 \pm \\
6.95\end{array}$ & $\begin{array}{c}60.09 \pm \\
7.77\end{array}$ & $\begin{array}{c}77.1 \pm \\
3.01\end{array}$ & $\begin{array}{c}53.78 \pm \\
5.87\end{array}$ & $\begin{array}{c}80.19 \pm \\
5.02\end{array}$ & $\begin{array}{c}57.26 \pm \\
2.83\end{array}$ & $\begin{array}{c}77.17 \pm \\
4.75\end{array}$ & $\begin{array}{c}88.32 \pm \\
8.46\end{array}$ & $\begin{array}{c}62.1 \pm \\
6.64\end{array}$ & $\begin{array}{c}79.33 \pm \\
8.07\end{array}$ \\
\hline D\&P & ND & ND & ND & ND & ND & ND & ND & ND & ND & ND & ND \\
\hline ANOVA & \multicolumn{11}{|c|}{$\mathrm{p}<0.0001(* * *)$} \\
\hline Dunnett vs. NC & - & $* * *$ & ns & ns & ns & $*$ & ns & ns & $* *$ & $\mathrm{~ns}$ & $*$ \\
\hline Dunnett vs. HC & - & - & $* * *$ & $* * *$ & $* * *$ & $* * *$ & $* * *$ & $* * *$ & $* * *$ & $* * *$ & $* * *$ \\
\hline Ef\% vs. NC & - & 176.88 & 10.97 & 41.72 & -1.13 & 47.4 & 5.07 & 41.85 & 62.35 & 14.15 & 45.82 \\
\hline Ef\% vs. HC & - & - & -55.99 & -48.4 & -64.36 & -46.85 & -64.1 & -48.86 & -24.79 & -58.84 & -47.42 \\
\hline Dunnett $v s$. Ref & - & - & - & ** & $\mathrm{ns}$ & $\mathrm{ns}$ & ns & ns & $\mathrm{ns}$ & $\mathrm{ns}$ & $\mathrm{ns}$ \\
\hline
\end{tabular}

$\mathrm{ND}=$ normal distribution; $\mathrm{ns}=$ no statistical significance

Table II

Variation of mean LDL cholesterol levels (mg/dL) compared to the control groups

\begin{tabular}{|c|c|c|c|c|c|c|c|c|c|c|c|}
\hline Group & $\begin{array}{c}\text { Normal } \\
\text { Control } \\
(\mathrm{NC})\end{array}$ & $\begin{array}{c}\text { Hyperlip } \\
\text { Control } \\
(\mathrm{HC})\end{array}$ & Ref & $\mathrm{C} 1$ & $\mathrm{C} 2$ & $\mathrm{C} 3$ & A1 & A2 & A5 & A6 & A7 \\
\hline $\mathrm{M} \pm \mathrm{SEM}$ & \begin{tabular}{|c|}
$18.09 \pm$ \\
3.04
\end{tabular} & $\begin{array}{c}81.00 \pm \\
4.11\end{array}$ & $\begin{array}{c}15.52 \pm \\
1.59\end{array}$ & $\begin{array}{c}34.37 \pm \\
4.87 \\
\end{array}$ & $\begin{array}{c}13.74 \pm \\
1.82\end{array}$ & $\begin{array}{c}15.24 \pm \\
3.56 \\
\end{array}$ & $\begin{array}{c}15.59 \pm \\
2.75\end{array}$ & $\begin{array}{c}22.37 \pm \\
2.17\end{array}$ & $\begin{array}{c}24.00 \pm \\
1.36\end{array}$ & $\begin{array}{c}14.66 \pm \\
1.81\end{array}$ & $\begin{array}{c}20.65 \pm \\
2.81 \\
\end{array}$ \\
\hline $\mathrm{D} \& \mathrm{P}$ & ND & ND & ND & ND & ND & ND & ND & ND & ND & ND & ND \\
\hline ANOVA & \multicolumn{11}{|c|}{$\mathrm{p}<0.0001(* * *)$} \\
\hline Dunnett $v s . \mathrm{NC}$ & - & $* * *$ & ns & $* *$ & ns & ns & ns & $\mathrm{ns}$ & ns & ns & ns \\
\hline Dunnett $v s . \mathrm{HC}$ & - & & $* * *$ & $* * *$ & $* * *$ & *** & $* * *$ & $* * *$ & $* * *$ & $* * *$ & $* * *$ \\
\hline $\mathrm{Ef} \%$ vs. NC & - & 347.76 & -14.20 & 89.99 & -33.23 & -15.74 & -13.81 & 23.65 & 32.66 & -18.96 & 14.15 \\
\hline $\mathrm{Ef} \%$ vs. HC & - & & -80.83 & -57.6 & -83.80 & -81.85 & -80.75 & -72.38 & -70.37 & -82.90 & -74.50 \\
\hline Dunnett $v s$. Ref & - & & & $* *$ & $\mathrm{~ns}$ & ns & $\mathrm{ns}$ & $\mathrm{ns}$ & $\mathrm{ns}$ & $\mathrm{ns}$ & ns \\
\hline
\end{tabular}

$\mathrm{ND}=$ normal distribution; $\mathrm{ns}=$ no statistical significance

Table III

Variation of mean HDL cholesterol levels (mg/dL) compared to the control groups

\begin{tabular}{|c|c|c|c|c|c|c|c|c|c|c|c|}
\hline Parameter & $\begin{array}{c}\text { Normal } \\
\text { Control } \\
(\mathrm{NC}) \\
\end{array}$ & $\begin{array}{c}\text { Hyperlip } \\
\text { Control } \\
(\mathrm{HC})\end{array}$ & Ref & $\mathrm{C} 1$ & $\mathrm{C} 2$ & $\mathrm{C} 3$ & $\mathrm{~A} 1$ & $\mathrm{~A} 2$ & A5 & A6 & A7 \\
\hline $\mathrm{M} \pm \mathrm{SEM}$ & $\begin{array}{c}28.40 \pm \\
3.31\end{array}$ & $\begin{array}{c}22.90 \pm \\
1.17\end{array}$ & $\begin{array}{c}32.01 \pm \\
6.51\end{array}$ & $\begin{array}{c}37.37 \pm \\
4.88\end{array}$ & $\begin{array}{c}40.46 \pm \\
3.98\end{array}$ & $\begin{array}{c}53.04 \pm \\
7.27\end{array}$ & $\begin{array}{c}39.53 \pm \\
4.53\end{array}$ & $\begin{array}{c}41.33 \pm \\
2.43\end{array}$ & $\begin{array}{c}49.22 \pm \\
7.22\end{array}$ & $\begin{array}{c}42.18 \pm \\
3.70\end{array}$ & $\begin{array}{c}45.18 \pm \\
3.50\end{array}$ \\
\hline D\&P & ND & ND & ND & ND & ND & ND & ND & ND & ND & ND & ND \\
\hline ANOVA & \multicolumn{11}{|c|}{$\mathrm{p}<0.0007(* * *)$} \\
\hline Dunnett $v s$. NC & - & ns & ns & ns & ns & $* *$ & ns & ns & $*$ & ns & ns \\
\hline Dunnett $v s . \mathrm{HC}$ & - & & $\mathrm{ns}$ & $\mathrm{ns}$ & $\mathrm{ns}$ & $* * *$ & $\mathrm{~ns}$ & ns & $* *$ & $*$ & $*$ \\
\hline Ef\% vs. NC & - & -19.57 & 12.71 & 31.58 & 42.46 & 86.76 & 39.19 & 45.52 & 73.30 & 50.42 & 59.08 \\
\hline $\mathrm{Ef} \% v s . \mathrm{HC}$ & - & - & 39.78 & 63.18 & 76.68 & 131.61 & 76.62 & 80.48 & 114.93 & 84.19 & 97.29 \\
\hline Dunnett vs. Ref & - & - & - & $\mathrm{ns}$ & ns & ns & $\mathrm{ns}$ & ns & $\mathrm{ns}$ & $\mathrm{ns}$ & ns \\
\hline
\end{tabular}

$\mathrm{ND}=$ normal distribution; $\mathrm{ns}=$ no statistical significance

Table IV

Variation of mean triglyceride levels $(\mathrm{mg} / \mathrm{dL})$ compared to the control groups

\begin{tabular}{|c|c|c|c|c|c|c|c|c|c|c|c|}
\hline Parameter & $\begin{array}{c}\text { Normal } \\
\text { Control } \\
(\mathrm{NC})\end{array}$ & $\begin{array}{c}\text { Hyperlip } \\
\text { Control } \\
(\mathrm{HC})\end{array}$ & Ref & $\mathrm{C} 1$ & $\mathrm{C} 2$ & $\mathrm{C} 3$ & $\mathrm{~A} 1$ & $\mathrm{~A} 2$ & A5 & $\overline{\mathrm{A} 6}$ & A7 \\
\hline $\mathrm{M} \pm \mathrm{SEM}$ & $\begin{array}{c}55.07 \pm \\
2.22 \\
\end{array}$ & $\begin{array}{c}140.6 \pm \\
9.35 \\
\end{array}$ & $\begin{array}{c}55.69 \pm \\
8.99 \\
\end{array}$ & $\begin{array}{c}62.30 \pm \\
5.86\end{array}$ & $\begin{array}{c}50.15 \pm \\
5.81 \\
\end{array}$ & $\begin{array}{c}47.26 \pm \\
10.80 \\
\end{array}$ & $\begin{array}{c}44.68 \pm \\
3.35 \\
\end{array}$ & $\begin{array}{c}49.31 \pm \\
4.08 \\
\end{array}$ & \begin{tabular}{|c|}
$44.85 \pm$ \\
2.69 \\
\end{tabular} & $\begin{array}{c}41.37 \pm \\
4.66 \\
\end{array}$ & $\begin{array}{c}38.66 \pm \\
3.35\end{array}$ \\
\hline D\&P & ND & ND & ND & ND & ND & ND & ND & ND & ND & ND & ND \\
\hline ANOVA & \multicolumn{11}{|c|}{$\mathrm{p}<0.0001(* * *)$} \\
\hline Dunnett vs. NC & - & $* * *$ & ns & ns & ns & ns & ns & ns & ns & ns & ns \\
\hline Dunnett vs. HC & - & & $* * *$ & $* * *$ & $* * *$ & $* * *$ & $* * *$ & $* * *$ & $* * *$ & $* * *$ & $* * *$ \\
\hline Ef\% vs. NC & - & 155.31 & 1.12 & 13.12 & -8.93 & -14.18 & -18.86 & -10.45 & -18.55 & -24.87 & -29.79 \\
\hline Ef\% vs. HC & - & & -60.39 & -55.7 & -64.33 & -66.38 & -68.22 & -64.92 & -68.10 & -70.57 & -72.5 \\
\hline Dunnett vs. Ref & - & & & ns & $\mathrm{ns}$ & ns & ns & ns & $\mathrm{ns}$ & ns & ns \\
\hline
\end{tabular}

$\mathrm{ND}=$ normal distribution; $\mathrm{ns}=$ no statistical significance 


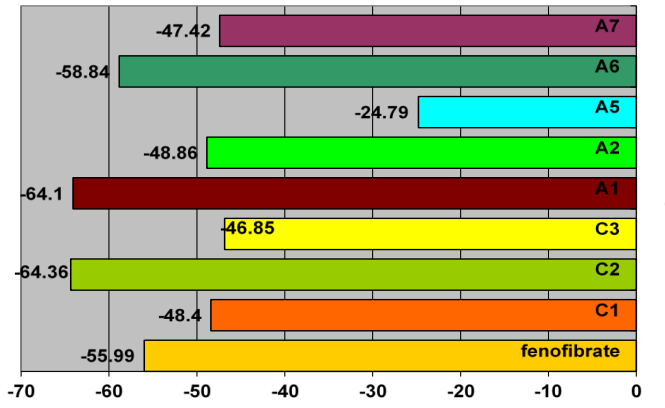

Figure 3.

Variation of average total cholesterol levels (\%) in the groups treated with the new compounds and reference substance compared to the hyperlipidemia control group

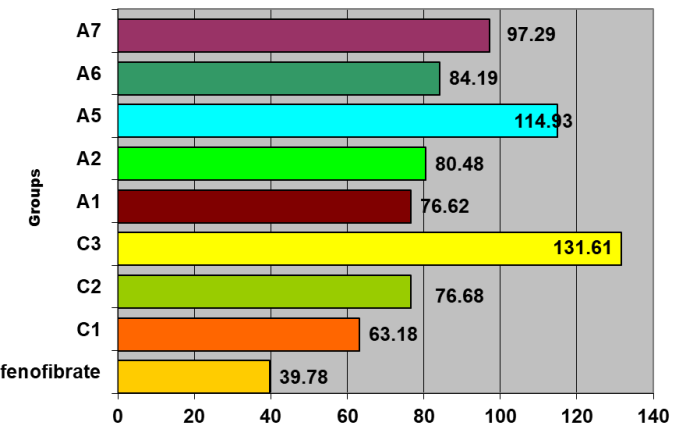

Figure 5.

Variation of average HDL-cholesterol levels (\%) in the groups treated with the new compounds and reference substance compared to the hyperlipidemia control group

Regarding the lipid peroxidation, expressed as MDA levels, our data showed a modulating effect of $\beta$ phenylethylamines (Figure 7).

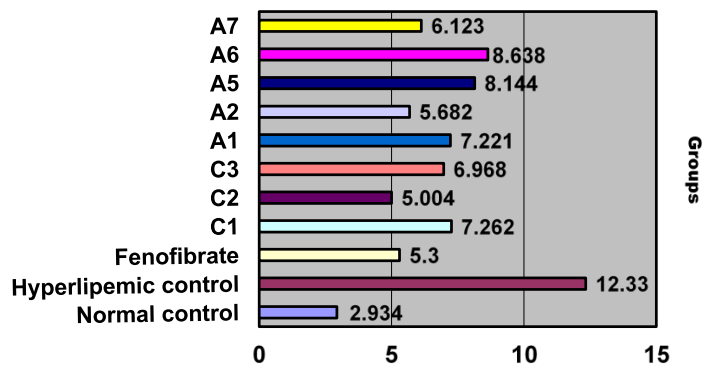

Figure 7.

MDA levels in the control, reference and test groups

All tested compounds reduced MDA levels compared to the hyperlipemic control group, some of them $(\mathrm{C} 2, \mathrm{C} 3, \mathrm{~A} 2, \mathrm{~A} 7)$ showing an effect similar to the reference substance $(p<0.001)$ (Figure 8$)$.

Additionally, a Pearson correlation coefficient of 0.0409 was determined, a significant positive correlation between hepatic MDA and HDL-cholesterol levels, for $\mathrm{C} 3$ derivative (Figure 9).

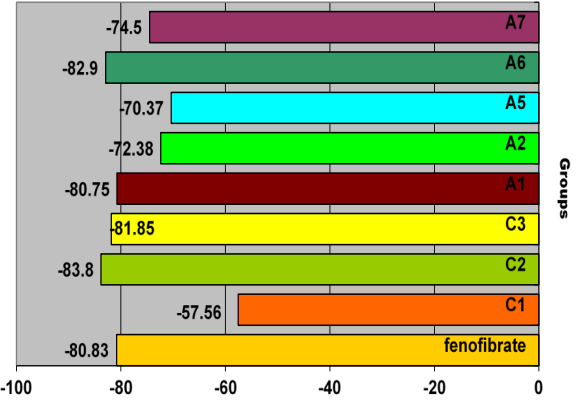

Figure 4.

Variation of average LDL-cholesterol levels (\%) in the groups treated with the new compounds and reference substance compared to the hyperlipidemia control group

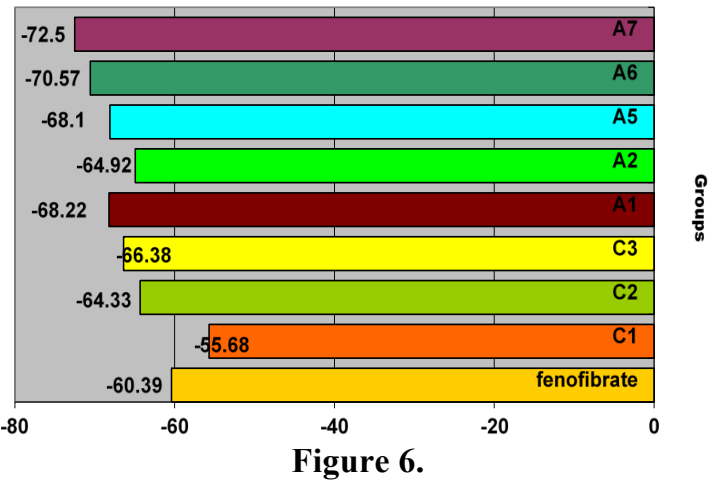

Variation of average triglyceride levels (\%) in the groups treated with the new compounds and reference substance compared to the hyperlipidemia control group

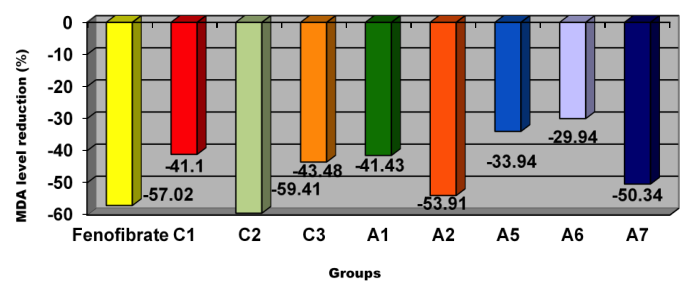

Figure 8.

MDA levels (\%) within the reference and test groups, compared to the hyperlipemic control group

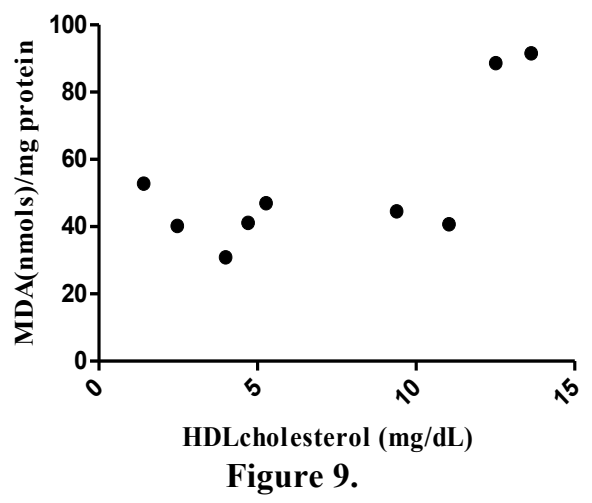

MDA/HDL cholesterol - Pearson correlation ( $\mathrm{p}=$ 0.0409 ) for the C3 group (100 mg/kg bw) 
FARMACIA, 2019, Vol. 67, 4

MDA, a marker of oxidative stress was shown to be altered in different stages of hyperlipidaemia in animal models [11, 21] as well as in humans [22]. HDL, a molecule with protective effect against oxidative stress, declines in hyperlipemia. Yang R et al. [22] revealed a negative correlation between these 2 parameters in hyperlipemic subjects, in accordance with our results. Our analysis u revealed a similar correlation between HDL and oxidative stress. Our study brings new approaches regarding the potential anti-lipidic effects of $\beta_{3}$ agonists and also as possible modulators of lipid peroxidation, results confirmed by other literature data $[19,20]$.

\section{Conclusions}

The newly $\beta$-phenylethylamine derivatives studied had a positive impact on the biomarkers of lipid metabolism disrupted by triton administration.

The molecules coded $\mathrm{C} 2$, A 1 and A6 lowered the total cholesterol higher than the reference substance. The effect was similar on LDL-cholesterol values. C3 and A5 significantly increased HDL-cholesterol, while triglycerides were highly lowered compared to with reference substance by all tested compounds, except for $\mathrm{C} 1$.

C2, C3, A2 and A7 had the most important effect in preventing lipid peroxidation. $\mathrm{C} 2$ reduced MDA levels higher than the reference substance. Furthermore, C3 molecule showed a positive correlation between HDL variation and MDA activity.

Our results confirmed the $\beta$-phenylethylamines therapeutic potential in treating lipid metabolism dysfunctions, therefore additional research is required in order to confirm these findings.

\section{References}

1. Bărbuceanu SF, Băncescu G, Șaramet G, Bărbuceanu F, Draghici C, Rădulescu FS, Ionescu A, Negreș S, Synthesis and biological evaluation of some new N 1-[4-(4-chlorophenylsulfonyl) benzoyl]-N4-(aryl)thiosemicarbazides and products of their cyclization. Heteroatom Chem., 2013; 24 (4): 309-321.

2. Chiriță C, Ștefănescu E, Marineci CD, Negreș S, Nuță DC, Experimental pharmacological research regarding some newly synthesized benzamides on the central nervous system. J Mind Med Sci., 2017; 4(2): 148-155.

3. Chiriță C, Cioroianu DM, Chiriță IC, Negreș S, Marian B, Zbârcea CE, Synthesis and pharmacological activity of new acyl-oximines derivatives. Farmacia, 2016; 64(1): 61-66.

4. Guţă R, Ilie C, Putina G, Nănău-Andreescu D, Negreș S, Căproiu MR, Potential antidiabetic/ antiobesity compounds from the beta-3-adrenergic receptors agonists class. Rev Chim (Bucharest), 2007; 58(10): 937-940.

5. Guță R, Putina G, Andreescu D, Ghiță C, Ilie C, Căproiu MR, Potential antidiabetic/ antiobesity compounds from the beta-3-adrenergic receptors agonists class (II). Rev Chim (Bucharest), 2012; 63(6): 565-570.
6. Ilieșiu AM, Pârvu I, Hodorogea AS, Nanea IT, Popescu AC, Perspectives in lipid lowering therapy. New therapies targeting LDL-cholesterol. Farmacia, 2018; 66(1): 8-17.

7. Kenji O, Matsui H, Yasuhiro O, Ryotaro T, Kenichiro M, Hajime I, Akiko I, Tomofumi M, Michitaka T, Yoko K, The polymorfism of the beta 3 adrenergic receptor gene is associated with reduced low-density lipoprotein particle size. Metabolism, 2003; 52(3): 356-361.

8. Klaus S, Seivert A, Boeuf S, Effect of beta 3 adrenergic agonist C1316,243 on functional differentiation of with and brown adipocytes in primary cell culture. Biochim Biophys Acta, 2001; 1539(1-2): 85-92.

9. Kostogrys RB, Pisulewski PM, Effect of conjugated linoleic acid (CLA) on lipid profile and liver histology in laboratory rats fed high-fructose diet. Environ Toxicol Pharmacol., 2010; 30(3): 245-250.

10. Mishra PR, Panda PK, Chowdary KA, Panigrahi S, Evaluation of acute hypolipidemic activity of different plant extracts in triton WR-1339 induced hyperlipidemia in albino rats. Pharmacologyonline 2011; 3: 925-934.

11. Minhajuddin M, Beg ZH, Iqbal J, Hypolipidemic and antioxidant properties of tocotrienol rich fraction isolated from rice bran oil in experimentally induced hyperlipidemic rats. Food Chem Toxicol., 2005; 43(5): 747-753.

12. Negreş S, Zanfirescu A, Ionică FE, Moroşan E, Velescu BȘ, Şeremet OC, Zbârcea CE, Ştefănescu E, Militaru M, Arsene AE, Margină DM, Uncu L, Scutari C, Chiriţă C, Pharmacotoxicological screening on new derivatives of beta-phenylethylamine, potential agonists of beta3-adrenergic receptors. Rom J Morphol Embryol., 2016; 57(3): 969-978.

13. Reitznerová A, Šuleková M, Nagy J, Marcinčák S, Semjon B, Čertík M, Klempová T, Lipid peroxidation process in meat and meat products: a comparison study of malondialdehyde determination between modified 2-thiobarbituric acid spectrophotometric method and reverse-phase high-performance liquid chromatography. Molecules, 2017; 22(11): 1-12.

14. Rose A, Funk D, Neiger R, Comparison of refractometry and biuret assay for measurement of total protein concentration in canine abdominal and pleural fluid specimens. J Am Vet Med Assoc., 2016; 248(7): 789-794.

15. Susulic VS, Frederich RC, Lawitts J, Tozzo E, Kahn BB, Harper ME, Himms-Hagen J, Flier JS, Lowell BB, Targeted disruption of the beta 3-adrenergic receptor gene. J Biol Chem., 1995; 270(49): 29483-29492.

16. Sen-Utsukarci B, Dosler S, Taskin T, Abudayyak M, Ozhan G, Mat A, AN Evaluation of antioxidant, antimicrobial, antibiofilm and cytotoxic activities of five Verbascum species in Turkey. Farmacia, 2018; 66(6): 1014-1020.

17. Ștefănescu E, Cristea AN, Chiriță C, Olaru O, Anghel A, Dinu M, Development and validation of Triticum phytobiological method as an alternative procedure for investigating in vivo acute toxicity on mice. J Mind Med Sci., 2017; 4(2): 178-185.

18. Ştefănescu E, Cristea AN, Chiriță C, Putina G, Experimental pharmacological research regarding the anti-obesity effect and the motor behavior induced by 
some newly synthetized $\beta_{3}$ adrenergic receptors agonists in normal mice. Farmacia, 2012; 60(3): 342-349.

19. Umekawa T, Yoshida T, Sakane N, Saito M, Kumamoto $\mathrm{K}$, Kondo M, Anti-obesity and anti-diabetic effects of CL316,243, a highly specific beta 3-adrenoceptor agonist, in Otsuka Long-Evans Tokushima fatty rats: induction of uncoupling protein and activation of glucose transporter 4 in white fat. Eur $J$ Endocrinol., 1997; 136(4): 429-437.

20. Warner A, Kjellstedt A, Carreras A, Böttcher G, Peng XR, Seale P, Oakes N, Lindén D, Activation of $\beta 3$ adrenoceptors increases in vivo free fatty acid uptake and utilization in brown but not white fat depots in high-fat-fed rats. Am J Physiol Endocrinol Metab., 2016; 311(6): E 901-E910.
21. Yang R, Le G, Li A, Zheng J, Shi Y, Effect of antioxidant capacity on blood lipid metabolism and lipoprotein lipase activity of rats fed a high-fat diet. Nutrition, 2006; 22(11-12): 1185-1191.

22. Yang RL, Shi YH, Hao G, Li W, Le GW, Increasing oxidative stress with progressive hyperlipidemia in human - relation between malondialdehyde and atherogenic index. J Clin Biochem Nutr., 2008; 43(3): 154-158.

23. Zhu C, Kar NF, Li B, Costa M, Dingley KH, Di Salvo J, Ha SN, Hurley AL, Li X, Miller RR, Salituro GM, Struthers M, Weber AE, Hale JJ, Edmondson SD, Discovery of benzamides as potent human $\beta 3$ adrenergic receptor agonists. Bioorg Med Chem Lett., 2016; 26(1): 55-59. 